
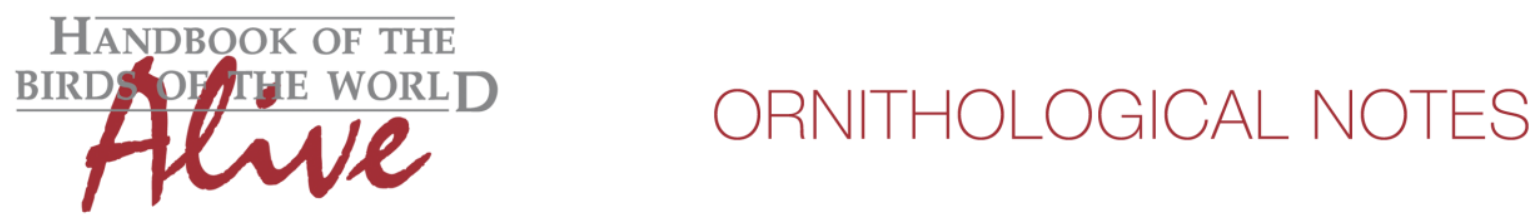

\title{
Notes on the vocalizations of Yellow-rumped Warbler (Dendroica coronata)
}

\section{Peter Boesman}

In the following we briefly analyze and compare voice of the different races of Yellowrumped Warbler (Dendroica coronata). We also try to quantify the extent of any vocal differences using the criteria proposed by Tobias et al. (2010), as a support for taxonomic review. We have made use of sound recordings available on-line from Xeno Canto (XC).

Two groups are generally recognized: Myrtle Warbler (races coronata and hooveri) and Audubon's Warbler (races auduboni, nigrifrons and goldmani). We will compare these two groups (the lack of definite sound recordings of races nigrifrons and goldmani does not allow to zoom in on possible further differences within the latter group).

\section{Call}

The main call note of Myrtle Warbler and Audubon's Warbler has been described as being different, with Audubon's sounding more rising (Sibley 2000). Differences are quite clear on a sonogram. Some examples:

Audubon's Warbler
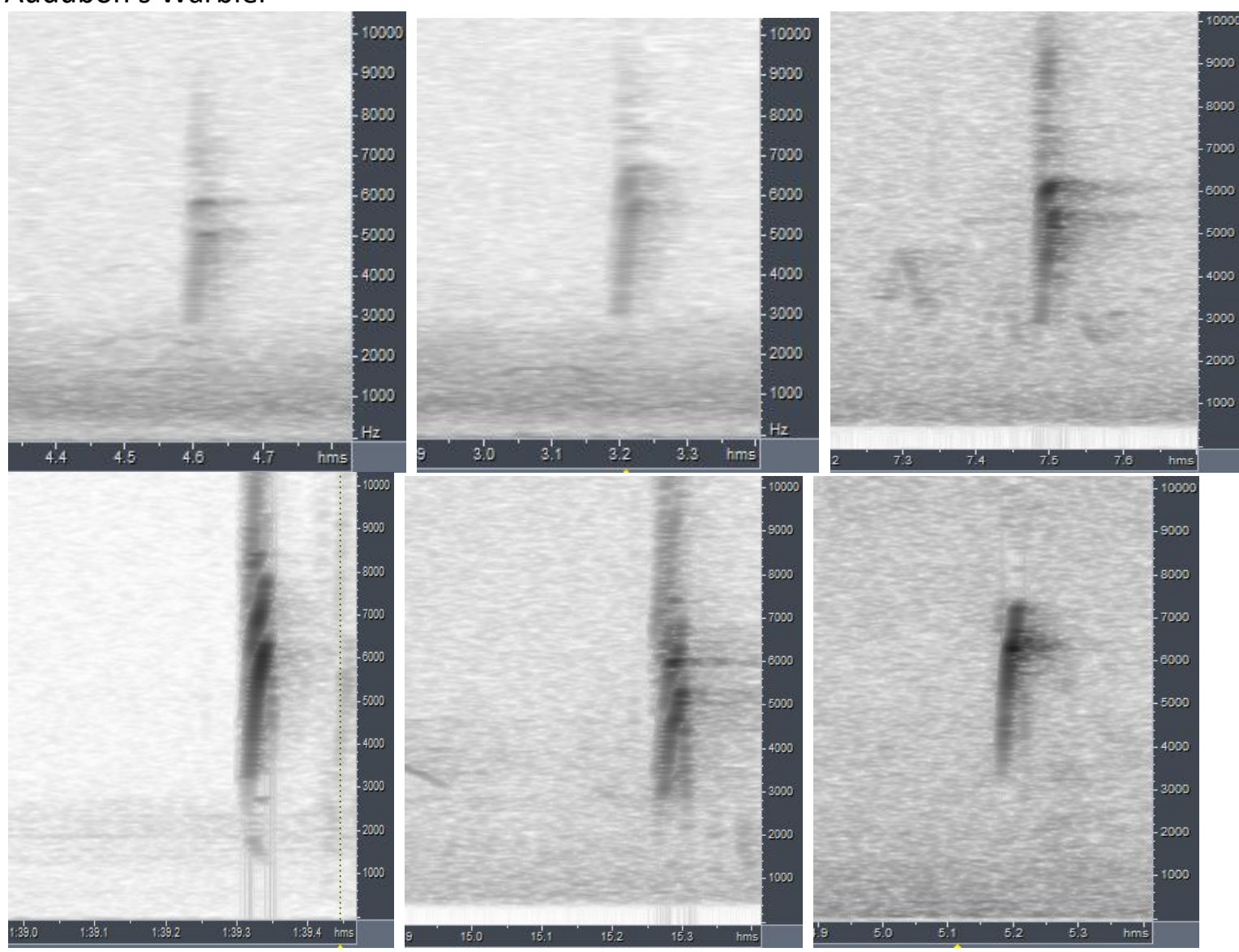


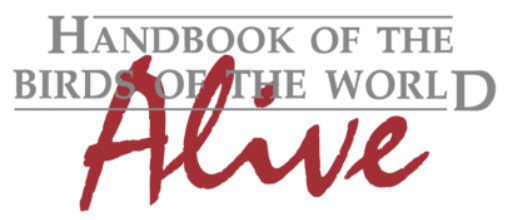

\section{ORNITHOLOGICAL NOTES}

Myrtle Warbler
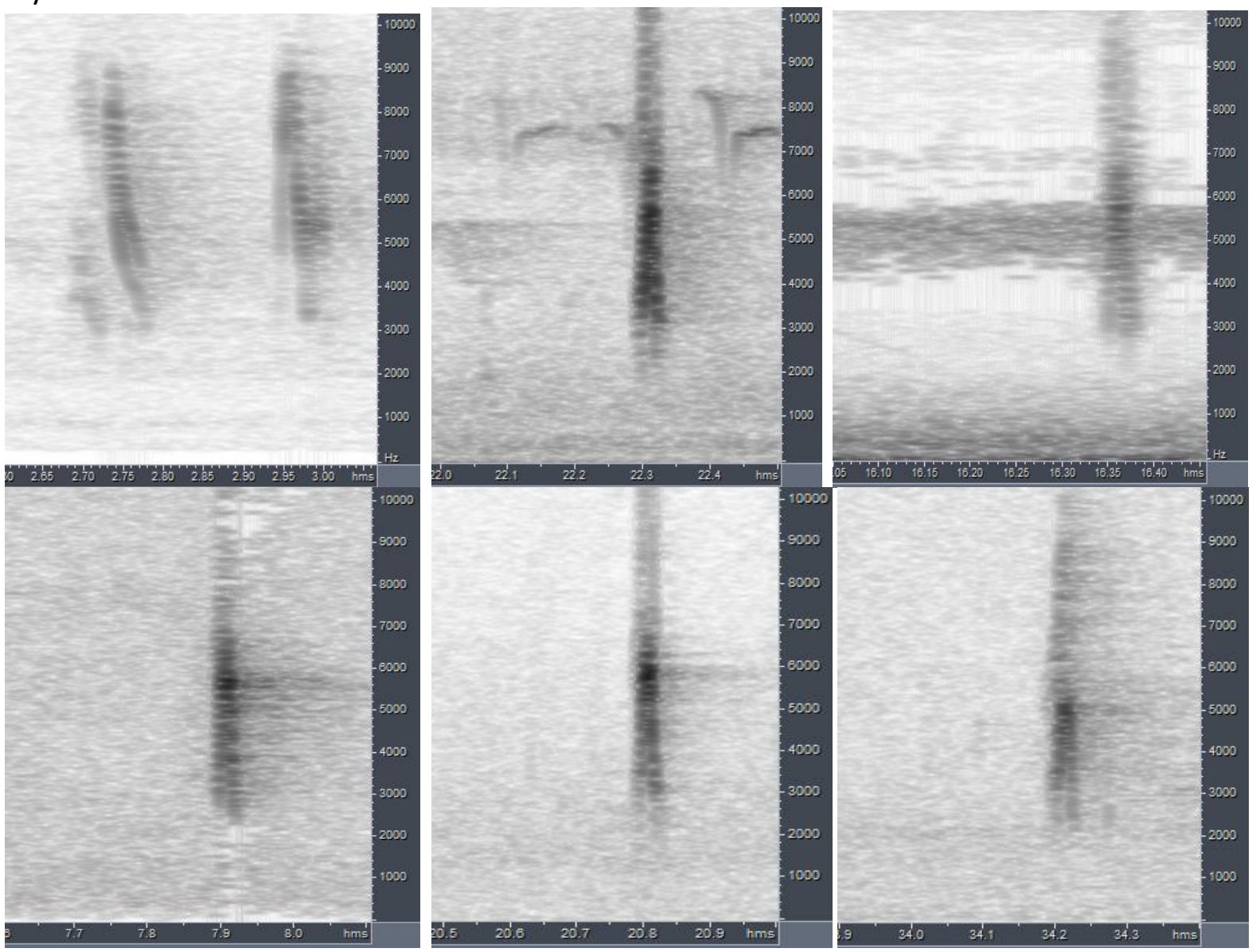

Audubon's Warbler has a note shape which is clearly rising, while Myrtle Warbler has a call which is clearly rising/falling (a sharp downturned V-shape). This difference is consistent over the entire range of both groups. Scoring of this vocal difference could be done e.g. on 'end frequency' or 'difference start frequency minus end freq.' , which is obviously much higher in Audubon's Warbler, leading to a score of about 3-4.

\section{Song}

Given the variability, differences in song are less obvious. Some examples:

Audubon's Warbler

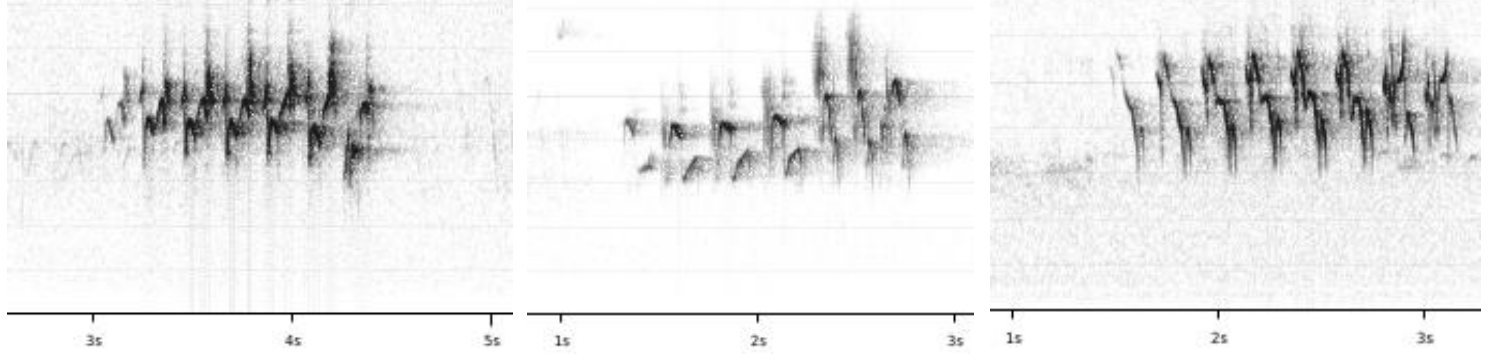



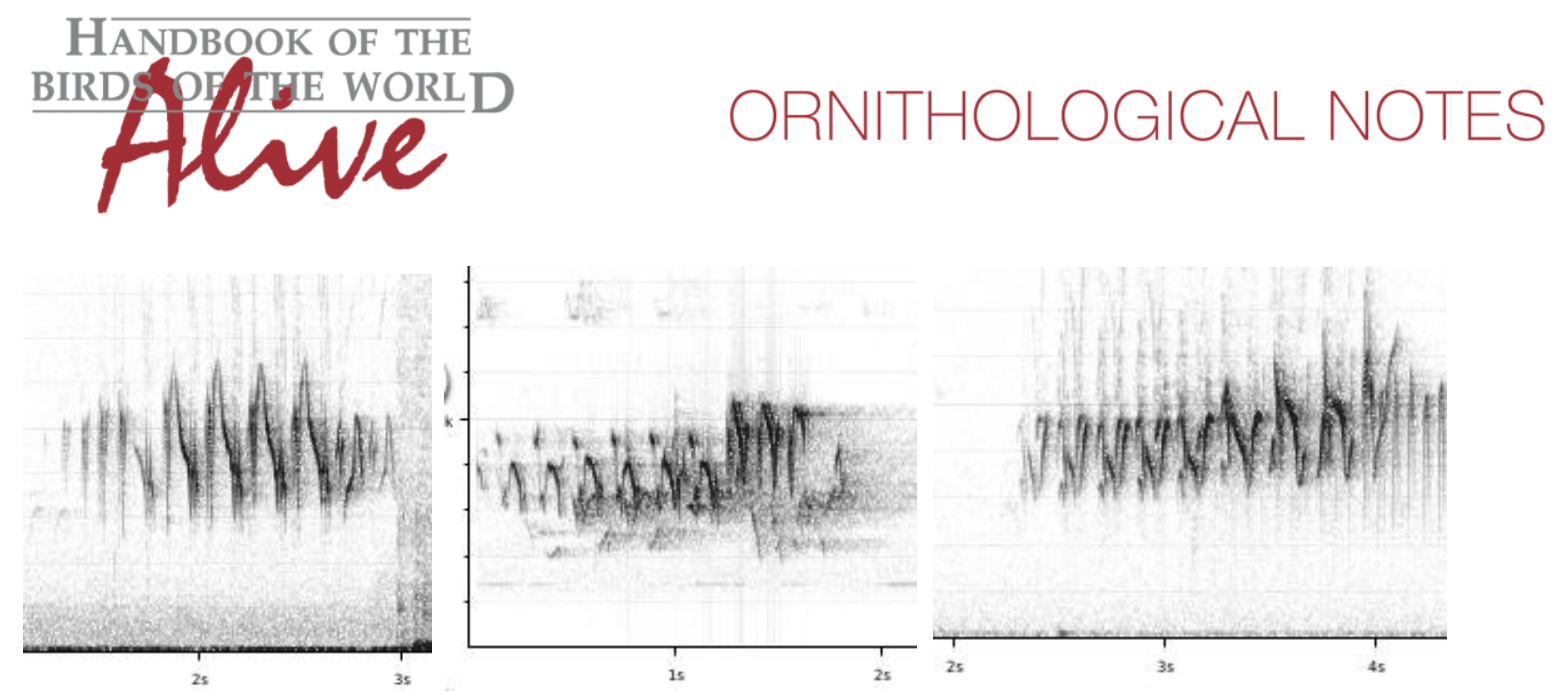

Myrtle Warbler
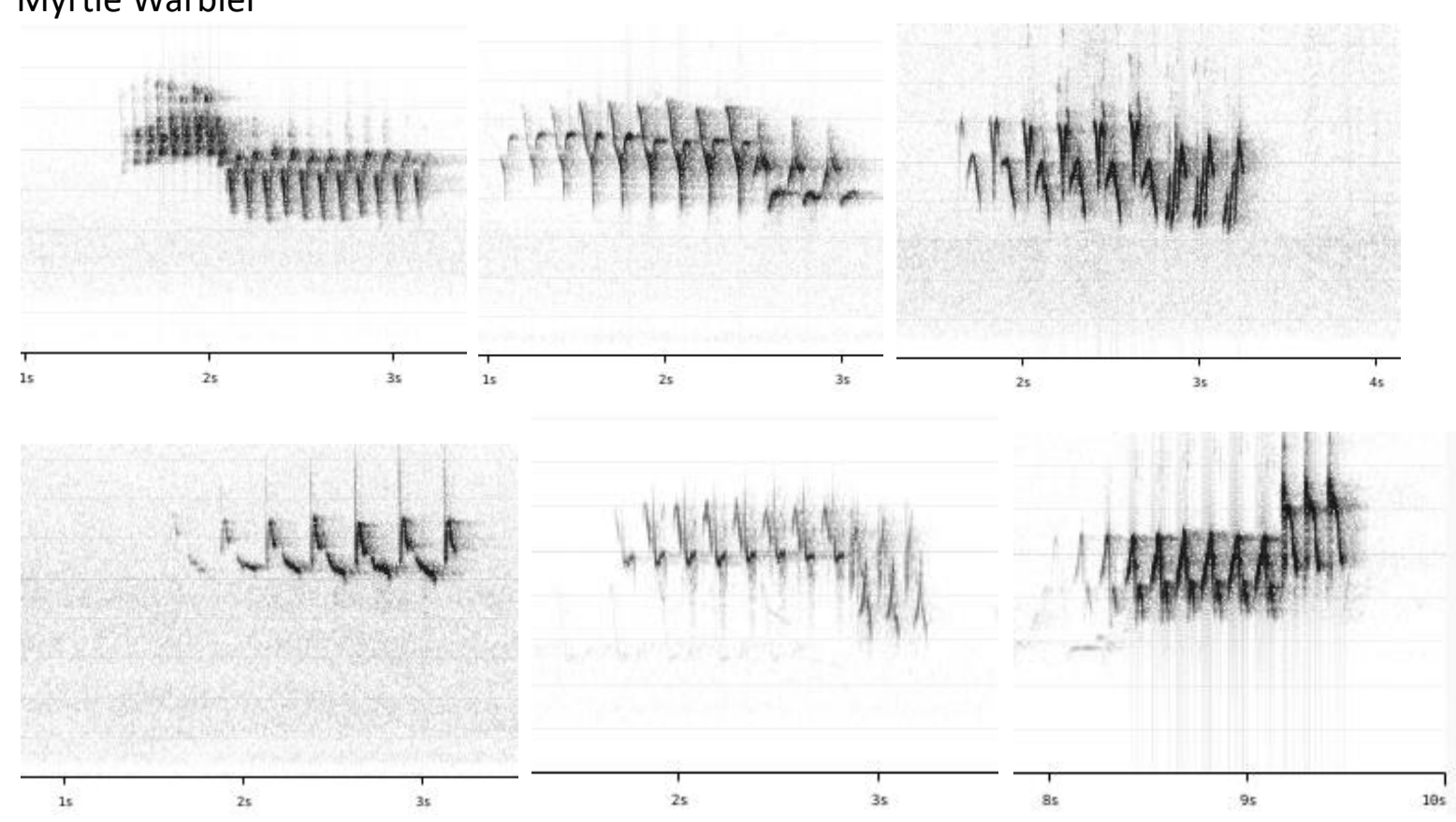

Myrtle Warbler has a song which is on average slightly higher-pitched than Audubon's. It often contains notes which are almost entirely above $5 \mathrm{kHz}$, which is seldom or never the case in Audubon's.

Audubon's Warbler typically has 7-9 'notes/subphrases' in song, Myrtle Warbler has often 912 'notes/subphrases' (occasionally less or more).

Other basic sound parameters are very similar, and there are at most slight differences of average values.

Song differences could thus be scored based on Audubon's lower number of notes (1) and lower frequency (1).

We can conclude that while there are minor differences in the song of both groups, it is mainly the call note which allows reliable identification with a high level of confidence.

This note was finalized on 27th June 2016, using sound recordings available on-line at that moment. We would like to thank in particular the many sound recordists who placed their recordings for this species on XC. 


\section{References}

Sibley, D. (2000). The Sibley Guide to Birds. National Audubon Society. Knopf, New York.

Tobias, J.A., Seddon, N., Spottiswoode, C.N., Pilgrim, J.D., Fishpool, L.D.C. \& Collar, N.J. (2010). Quantitative criteria for species delimitation. Ibis 152(4): 724-746.

\section{Recommended citation}

Boesman, P. (2016). Notes on the vocalizations of Yellow-rumped Warbler (Dendroica coronata). HBW Alive Ornithological Note 373. In: Handbook of the Birds of the World Alive. Lynx Edicions, Barcelona. (retrieved from http://www.hbw.com/node/1252923 on 29 November 2016). 